\title{
4D printing with smart materials and structures
}

\section{Hyeonseo Song, Jiyun Kim ${ }^{\dagger}$}

School of Materials Science and Engineering, Ulsan National Institute of Science and Technology, Ulsan 44919, Korea

\section{스마트 소재 및 구조 기반 4D 프린팅 기술 동향}

\author{
송현서, 김지윤 ${ }^{\dagger}$ \\ 울산과학기술원 신소재공학부
}

(Received March 2, 2020; Accepted March 17, 2020)

\begin{abstract}
s
Recently, 4D printing technology has received considerable attention in various industries and research fields including soft robotics, tissue engineering, electronics. In 4D printing process, 3D printed object transforms itself into programmed structure by the input of external energy. Thus, this process requires not only smart materials, capable of changing their properties or features in response to external stimuli such as electricity, temperature, light, etc., but also smart structures, multi-material 3D printing, simulation and so on. In this review, the concept, technical elements and potential of $4 \mathrm{~d}$ printing are presented.
\end{abstract}

Keywords: 4D printing, Smart materials, Programmable matter, Smart structure, 3D printing

\section{서론}

초지능, 초연결, 초융합 사회를 지향하는 4 차 산업혁 명의 시대가 도래했다. 이에 IoT, 빅데이터, 인공지능 등의 다양한 디지털 기술과 기기들을 기반으로 산업의 경계를 뛰어넘고 사람과 사물, 사물과 사물의 관계를 재
정립하려는 시도들이 많아지고 있다. 그러나 진정한 초 지능 사회로 진입하기 위해서는, 정적인 디지털 기기에 서 나아가 사물에 대한 새로운 관점이 필요하다. 즉, 사 물이 무형의 정보를 처리하는 것 뿐만 아니라 겉으로 보 여지는 형상과 물성 자체를 변화시키고 프로그래밍할 수 있다면, 사람과 사물, 사물과 사물 간의 관계가 혁신

${ }^{\dagger}$ Corresponding Author: Jiyun Kim

E-mail: jiyunkim@unist.ac.kr 
a)

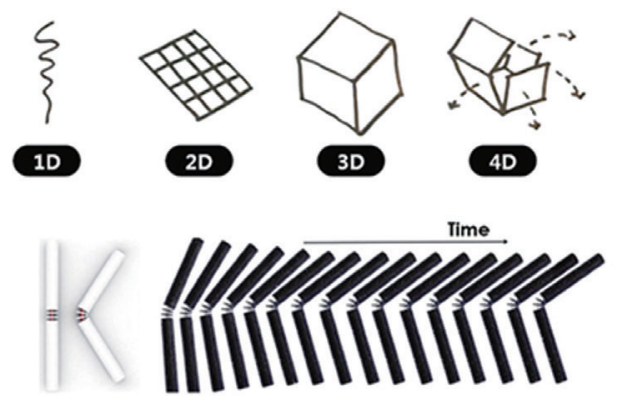

b)

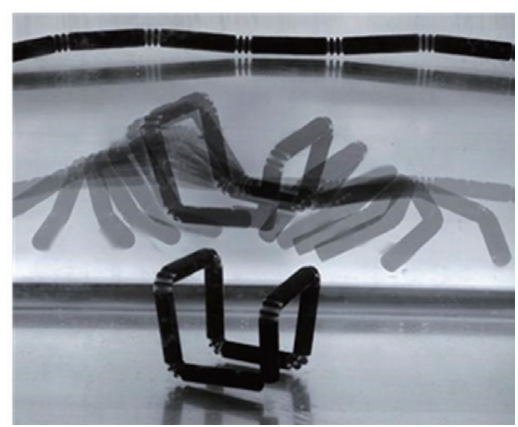

Fig. 1. a) $4 \mathrm{D}$ 프린팅의 개념 ${ }^{4-6)}$ b) MIT 자가조립연구소에서 개발한 $4 \mathrm{D}$ 프린팅 구조물

적으로 재정립될 수 있을 것이다.

이러한 사물 지능을 구현하기 위해서는 형상 및 물성 을 변화시킬 수 있는 소재들이 필요한데, 이들은 넓게 프로그래머블 소재 (Programmable Matter)로 불리고 있다. 가장 근본적이고 혁신적 개념으로는 카네기멜론 S. G. Goldstein 연구팀이 제안한 'Claytronics'가 있 으나 이 개념에서 요구하는 초지능 나노로봇 (Catom) 을 만들고 제어하는 것은 매우 어려운 일이라 아직까지 는 현실성이 부족하다. ${ }^{1)}$ 이 밖에도, 군집 로봇 (Swarm robotics $)^{2)}$ 이나 모듈화된 로봇 (Modular robot) ${ }^{3)}$ 의 형 태로 연구한 사례들이 있으나, 구성된 형상의 복잡도나 해상도 측면에서 아직 부족한 부분이 많다. 이에 프로 그래머블 소재를 구현하기 위한 또 다른 기술로, 스마트 소재와 이들의 자기조립을 이용한 $4 \mathrm{D}$ 프린팅 기술이 연 구되어 왔다. 그러므로 본고에서는 $4 \mathrm{D}$ 프린팅의 정의와 기술 요소들을 소개하고자 한다.

\section{2. 본문}

\section{1. $4 \mathrm{D}$ 프린팅의 정의}

$4 \mathrm{D}$ 프린팅에 앞서 3D 프린팅의 특징을 살펴보자면, $3 \mathrm{D}$ 프린팅은 기존의 금형이나 절삭이 아닌, 재료를 한 층씩 쌓는 적층 방식 (Additive manufacturing)을 이 용해 3차원 사물을 만드는 기술이다. 다양한 프린팅 재 료를 이용해 복잡하고 정밀한 형상의 사물을 제작할 수 있기 때문에 그 응용 분야가 넓을 뿐 아니라, 제조공정 의 간소화, 다품종 소량 생산을 가능하게 하여 신시장을
창출하고 전통적인 산업 구조에 큰 영향을 미치고 있다. 하지만 이러한 $3 \mathrm{D}$ 프린팅의 장점에도 불구하고, 기존 의 $3 \mathrm{D}$ 프린팅은 정적인 사물만을 생산하기 때문에 초지 능 사회 진입을 위한 스마트 사물을 제작하기에는 부족 함이 따른다. 이를 위해 제안되고 개발 중인 기술이 $4 \mathrm{D}$ 프린팅 기술이다. 4D 프린팅은 2013년 미국 MIT 자가 조립연구소 (Self-assembly Lab)의 Skylar Tibbits 교수가 " $4 \mathrm{D}$ 프린팅의 출현 (The emergence of 4D printing)' 이라는 제목의 TED 강연에서 처음 제안한 개 념으로, ${ }^{4} 3 \mathrm{D}$ 프린팅에서 파생된 개념이다. $3 \mathrm{D}$ 프린팅 이 개인이 상상하고 설계한 가상의 형상을 그대로 물리 적 세계에 실현시켜주는 기술이라면, $4 \mathrm{D}$ 프린팅은 온도 나 습도 등의 외부 자극 요소에 의해 따라 $3 \mathrm{D}$ 프린팅된 사물이 시간에 따라 스스로 물성이나 형상을 변화할 수 있게 만드는 기술이다 (Fig. 1). ${ }^{5-7)}$ 즉, 4D 프린팅 기술 을 이용하면, 자극 반응형 스마트 소재를 잘 설계된 3차 원 구조로 프린팅할 수 있기 때문에, $3 \mathrm{D}$ 프린팅된 제품 의 정적인 특징을 극복하고 외부 환경에 스마트하게 적 응하는 능동적인 제품들을 생산 할 수 있다. 이러한 관 점에서 $4 \mathrm{D}$ 프린팅은 소프트 로보틱스, 바이오 프린팅, 패션, 예술, 건축, 자동차, 의료, 컨텐츠 등 기존 $3 \mathrm{D}$ 프 린팅의 응용 분야를 모두 포함할 수 있고, 나아가 지능 형 기능을 기반으로 새로운 시장을 창출할 수 있는 가능 성을 지니고 있다.

$4 \mathrm{D}$ 프린팅 기술에서 가장 핵심이 되는 기술 요소들은 (1) 프린팅이 가능한 스마트 소재, (2) 다중물질의 형상 을 디자인하는 구조, (3) 스마트 소재의 $3 \mathrm{D}$ 프린팅 기술 


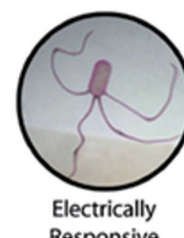

Responsive
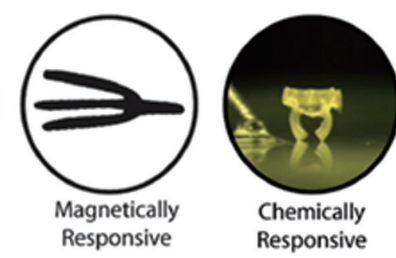

Fig. 2. 스마트 소재 (자극 반응형 소재)의 외부 자극에 따른 분류")

\subsection{D 프린팅과 스마트 소재}

$4 \mathrm{D}$ 프린팅에서 가장 핵심적인 부분 중 하나는 자극 반응형 소재 (Stimuli-responsive material), 또는 스 마트 소재 (Smart material)이다. 스마트 소재들을 적 절하게 설계하여 $3 \mathrm{D}$ 프린팅으로 제작하는 것이 $4 \mathrm{D}$ 프 린팅 기술이기 때문이다.

\subsection{1. 스마트 소재의 종류}

스마트 소재란 특정 외부환경의 자극에 반응하여 형 상 또는 물성을 변화시킬 수 있는 소재를 의미한다. 이 러한 반응을 외부 자극에 적응하는 지능적 거동이라 일 컬으며, 외부 자극에는 습도, 온도, 전,자기장, 압력, 빛, 표면장력 등 매우 다양한 에너지원이 포함된다. 대 부분의 스마트 소재는 한 가지 자극에 한 종류의 기능 변화를 보여주는데, 예를 들어 온도가 높아지면 구부러 지는 등 아직까지는 기초적인 기능 수준에서 동작한다. 하지만 추가적인 기능과 물성을 조합하면 복잡한 전기/ 기계적 시스템의 부품으로 활용될 수 있다. 이러한 특징 을 기반으로 스마트 소재는 액추에이터, 센서부터 자동 차, 로봇, 생체의료소자, 에너지 하베스팅 소자까지 다 양한 분야에 이르는 응용 분야에 활용되는 연구가 이루 어지고 있다. ${ }^{8)}$

이러한 스마트 소재를 분류하기 위해 사용될 수 있 는 기준은 다양하다. 그 중에서, 소재에 가해지는 외 부 자극의 종류를 기준으로 소재를 분류하면 대표적 인 스마트 소재들은 다음과 같이 분류된다. ${ }^{9)}$ (1) 전 기 자극에 반응하는 전도성 고분자 (Conductive polymer), 이온성 고분자 (Ionic polymer), 액정 탄

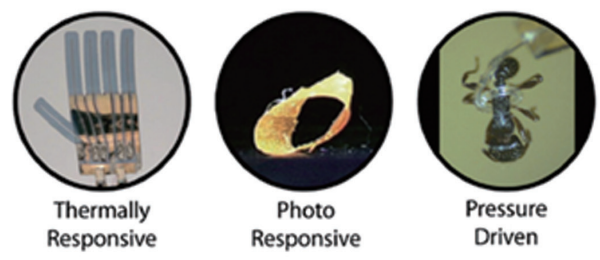

성 중합체(Liquid crystal elastomer), 유전 탄성 체 (Dielectric elastomeric actuator), 전기 유변 유체 (Electrorheological Fluid), 전기 전도성 복 합체(Conductive composite). (2) 자기 자극에 반 응하는 자성 유체 (Ferrofluid), 자기 유변 유체 (Magnetorheological fluid)), 자성 복합체 (Magnetic composite). (3) 온도에 반응하는 형상 기억 고분자 (Shape memory polymer), 형상 기억 합금 (Shape memory alloy), 액정 탄성 중합체 (Liquid crystal elastomer), 하이드로젤 (Hydrogel), 액체 금속 (Liquid metal). (4) 빛에 반응하는 아조벤젠 기반 고 분자 (Azobenzene containing polymer). (5) 내부 유 체의 압력에 변형되는 탄성 중합체 (Elastomer) 등이 있다.

\subsection{2. 스마트 소재의 프린팅 가능성}

위의 모든 스마트 소재가 $4 \mathrm{D}$ 프린팅 소재로 사용될 수 있는 것은 아니다. 스마트 소재를 4D 프린팅 하는데 있어서 가장 중요한 것은 일단 $3 \mathrm{D}$ 프린팅이 가능한 소 재여야 한다는 것이다. $4 \mathrm{D}$ 프린팅을 달성하는 가장 간 단한 방법으로 단일 스마트 재료를 사용한 $3 \mathrm{D}$ 프린팅을 하는 것이 있다. 예를 들어, 고분자 소재의 경우, 열경 화, 광경화 등을 통해 재작할 수 있는 기본 소재들이 매 우 많기 때문에 FDM, SLA 등의 방식을 이용해 $4 \mathrm{D}$ 프 린팅을 구현하기에 유리하다.

프린팅 가능한 물질에 스마트 기능성 소재들을 섞어 복합재를 만드는 것 역시, 스마트 소재를 이용하여 $4 \mathrm{D}$ 프린팅을 할 수 있는 소재를 만드는 방법이다. 즉, 형상 기억 고분자, 탄성 중합체, 하이드로겔 등을 이용해 복 합체를 만들면 $3 \mathrm{D}$ 프린팅이 가능한 다양한 스마트 소 
재를 제작할 수 있다. 예를 들어, 온도 변화에 반응하는 스마트 소재와 특정 파장의 빛에 열을 발생시키는 입자 를 이용해 복합체를 제작하면, 빛에 반응하는 스마트 소 재를 제작할 수 있다. ${ }^{10)}$ 또한, 자성 입자와 프린팅 가능 한 탄성중합체를 이용한 복합체를 제작하면, 프린팅 과 정에서 자성 특성을 프로그래밍할 수 있는 복잡도 높은 스마트 소재 및 구조를 제작할 수 있다. ${ }^{11)}$ 이러한 방법은 소재의 자극 반응 정도 뿐만 아니라 자극 반응 인터페이 스를 제어할 수 있기 때문에 $4 \mathrm{D}$ 프린팅에 적용 가능한 스마트 소재의 범위를 넓힐 수 있다. 또한, 이러한 방법 들로 다양한 스마트소재를 구조적으로 집적하여 프린팅 한 물체의 형상과 물성 변화를 프로그래밍할 수 있게 되 면 $^{12-13)}$, 복잡한 작동을 필요로 하는 로봇 공학 및 생물 의학 등 광범위한 분양에서 $4 \mathrm{D}$ 프린팅의 응용 분야를 찾을 수 있을 것이다.

\subsection{D 프린팅과 스마트 구조}

생체 소재들은 이미 다양한 수준의 형상, 물성, 구조 적 기능을 가지고 있다. 예를 들어 생체 내 생명정보의 핵심인 DNA와 생명활동의 핵심인 단백질은 모두 1차 원 형태의 기본 분자 시퀀스가 3 차원으로 자기조립 되 어있고, 필요할 경우 형상 변화를 통해 정보를 전달하거 나 다양한 기능을 수행할 수 있다. 이러한 구조적 설계 는 구조를 구성하는 단일 유닛의 기능에서 나아가 구조 자체로 인한 창발적 기능을 가질 수 있게 한다. 그에 비 해 한 가지 물성의 스마트 소재 자체는 보통 단순 변형 만 나타내기 때문에, 이들의 단순 변형을 구조적으로 설 계하여 자기조립을 통해 복잡한 형상을 만드는 것이 $4 \mathrm{D}$ 프린팅의 핵심 목표이다. 자기조립의 과정에서 원하는 형상을 어떤 방식으로 만들어낼 수 있느냐에 따라 다양 한 구조적 설계 원리가 존재한다. 아래의 내용에서는 그 러한 다양한 구조적 설계 방법들인 스마트 구조들을 소 개한다.

\subsection{1. 오리가미}

종이 접기 (Origami)는 단순한 놀이나 예술적 의미에 서 나아가, 엔지니어링 장치 및 구조물 디자인을 위한
하나의 설계 방식으로 활용되고 있다. ${ }^{14)}$ 종이접기 구조 는 제작이 쉬울 뿐만 아니라 새로운 형태로 재구성하는 것이 용이하며,고, 제작, 조립, 보관 및 변형 등 여러 측 면에서 장점을 가지고 있다. 또한, 이러한 설계 원리가 거의 모든 스케일에 적용될 수 있다는 것 역시 종이접기 의 큰 장점 중 하나이다. 예를 들어, 이미 생명체는 생체 소재인 DNA나 단백질을 접힘 (Folding) 기반으로 나노 스케일에서 구조를 집적한다. 이를 모방하여, 1980년대 에 $\mathrm{DNA}$ 를 접어서 나노 스케일의 빌딩 블록을 만들었던 연구와 ${ }^{15)} 2000$ 년대에 DNA 사슬을 원하는 대로 접어 원 하는 형상을 만들었던 DNA origami ${ }^{16)}$ 연구를 시작으로 나노스케일에서 종이 접기 원리를 활용한 다양한 연구 들을 찾아볼 수 있다.

오리가미 구조는 기본구조를 접는 순서와 방식에 따 라 자유로운 형상 변형이 가능하다는 특징을 가지고 있 기 때문에, $4 \mathrm{D}$ 프린팅 분야에서도 활발하게 이용되고 있는 구조 설계법이다. $4 \mathrm{D}$ 프린팅 구조에서 접히는 부 분을 스마트 소재로 구성하면, 외부 자극에 따라 해당 부분이 접히거나 변형되며 원하는 형상으로 스스로 모 양이 바뀌게 된다. 나아가, 기존의 오리가미 구조가 단 순히 접혔을 때는 접히는 부분이 견딜 수 있는 하중이 약하다는 점을 보완하기 위해서, 최근에는 쌍안정 구조 (Bistable structure)를 이용한 스프링 오리가미 (Sping origami) 설계법이 제안되어, ${ }^{17}$ ) 오리가미 구조를 더 효 과적으로 이용할 수 있는 4D 프린팅 기술이 발전하고 있다. 오리가미 구조는 각 모듈들 사이의 통신 및 결합 으르 이용해서 여러 가지 형태로 구조를 변화시킬 수 있 는 모듈형 로봇, ${ }^{18)}$ 그리고 우주선에서 태양 빛을 능동적 으로 가릴 수 있는 구조까지 ${ }^{19}$ 거의 모든 스케일의 시스 템에서 다양한 형태로 응용되어 그 가치를 증명하고 있 기 때문에, $4 \mathrm{D}$ 프린팅 구조와 다양한 시스템을 결합시 키는 데에도 매우 유리한 설계법이 될 수 있다.

\subsection{2 키리가미}

키리가미는 오리가미의 변형된 형태로, 접은 종이를 미리 디자인된 선을 따라 칼로 흠집을 낸 뒤 종이를 살 짝 잡아당겨 3차원 형상을 만드는 구조로, 키리가미 구 
a)

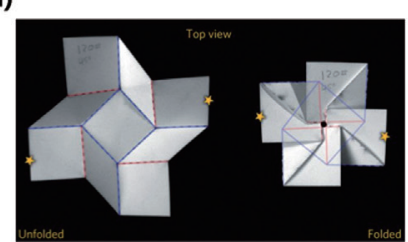

b)

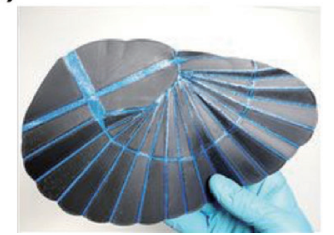

c)

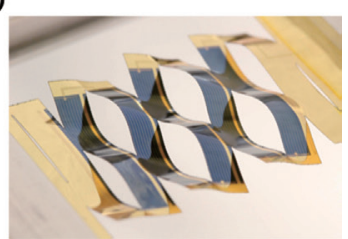

Fig. 3. a) 오리가미 구조물의 접기 전과 접기 후 모습 ${ }^{(4)}$ b) 스프링 오리가미 구조를 이용한 날개형 액츄에이터() ${ }^{(1)}$ 키리가미 구조를 이용한 태양전지판 ${ }^{20}$

조는 간단한 과정을 통해 2 차원 에서 3 차원 구조를 만 들 수 있다는 장점 때문에 소자설계 뿐 아니라 나노소재 의 물리적 특징을 설계하는데도 사용된다. 2015년의 미 시건 대학교 연구진들은 이러한 키리가미 구조의 장점 을 활용하여 제시한 새로운 형태의 태양 전지판을 제시 했다. ${ }^{20)}$ 이것은 얇고 잘 휘는 넓은 태양 전지판 평면에 미리 디자인된 절단 패턴을 따라 절단을 만들고 이것을 살짝 잡아당겨 만든 3 차원 형태의 태양전지판이다. 이 렇게 만들어진 3 차원 태양전지판은 2 차원 평면 형태에 비해 다양한 각도의 기울기가 형성되어, 달라지는 태양 위치에 따라 태양 에너지 흡수 효율을 높일 수 있었다.

키리가미 구조를 적용하는 물질이 종이에서 다양한 재료들로 확장되면, 재료에 추가된 절단 패턴에 따라 재 료의 탄성 및 변형 정도 조정이 가능해진다. 2015 년에 는 코넬 대학교 연구팀이 이를 활용하면 신축성을 갖는 전기 전도성 소재 개발 방안을 제시했다. ${ }^{21)}$ 그래핀은 탄 소 원자들이 결합하여 만든 육각형 벌집 모형의 2 차원 소재이며 높은 안정성을 갖는 반면 인장력을 가하면 찢 어지는 성질을 가진다. 이것은 2 차원 소재의 특징상 인 장력이 가해졌을 때 특정 부분에 힘이 집중되면서 소재 가 견디지 못하기 때문이다. 하지만, 수학적 계산을 바 탕으로 소재에 절단 패턴을 추가하면, 인장력을 가할 때 는 힘이 분산되어 소재의 3 차원적인 변형이 일어나고, 힘을 제거할 경우 원래 상태로 돌아가는 신축성이 부여 되는 것이다.

키리가미 구조 역시 4D 프린팅 구조로 활용될 수 있 는데, 최근 하버드대학교 연구진들의 키리가미 기반의 스마트 액츄에이터를 이용한 소프트 로봇 개발했을 뿐 아니라 $3 \mathrm{D}$ 프린팅을 이용한 키리가미 기반 액츄에이터
등이 다양하게 연구되고 있다. 키리가미 구조도 오리가 미 구조와 같이 스마트 소재를 4D 프린팅 하는 효과적 인 하나의 구조로 자리를 잡아갈 것이다. ${ }^{22-24)}$

\subsection{3. 메타물질}

메타물질 (Metamaterial)은 자연계 물질로는 실현 될 수 없는 특성이나 기능을 가지도록 인위적으로 설계 된 물질을 의미한다. 여기서 메타물질의 특성은 메타물 질을 구성하는 분자나 물질의 자체적 물성보다 인위적 으로 설계된 반복 구조에 의해 발현된다. 즉, 물질을 이 루는 반복되는 구조의 배열과 패턴 등이 메타물질의 새 로운 물리적 특성을 만드는데 중요한 역할을 하는 것 이다. 대표적인 메타물질로는 광 메타물질 (Photonic metamaterial)이 있다. 물질 내 구조들의 크기와 간격 을 이용하여, 예를 들어 유전율 또는 투자율이 음의 값 을 가져 음의 굴절률을 가지고 있는, 자연계에 존재하지 않는 광학적 물질을 설계할 수 있다. ${ }^{25)}$ 이러한 광 메타 물질은 투명망토, 고성능 렌즈, 고효율 파동 흡수제 등 여러 분야에 적용될 수 있어 큰 주목을 받고 있다.

광 메타 물질 외에, 자연계에는 존재하지 않던 기 계적 물성을 보여주는 기계적 메타물질 (Mechanical metamaterial) 이 있다. 이들이 보여주는 독특한 기계 적 물성들 중에는 대표적으로 음성 푸아송 비 (Negative Poisson's Ration, NPR) 가 있다. ${ }^{26-27)}$ 자연계 물질들은 일반적으로 양의 푸아송 비 (Positive Poisson's ratio) 를 가지는데, 외력에 따라 변형되더라도 부피를 유지하 려는 특징 때문에 특정한 방향을 따라 압축(신장)될 때 가해진 힘에 수직인 방향으로 팽창(수축)하려는 성질을 보인다. 반면 NPR를 갖는 기계적 메타물질들은 오히려 


\section{특 집 묘 송현서, 김지윤}

a)

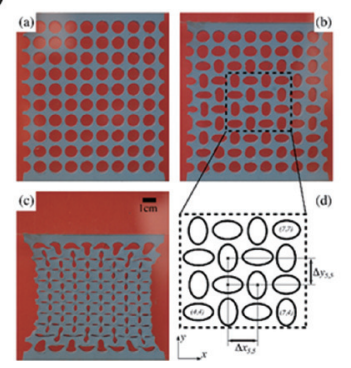

b)

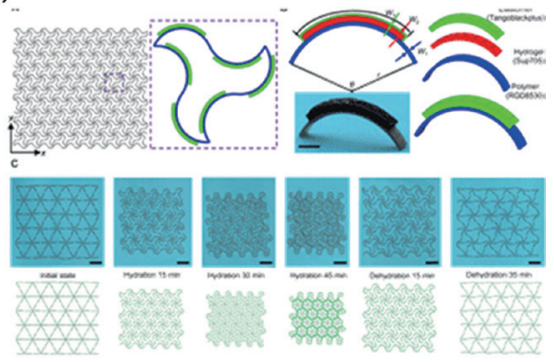

Fig. 4. a) 기계적 메타물질 ${ }^{26)}$ b) 스마트 소재를 이용해 만든 기계적 메타물질 ${ }^{28)}$

압축(신장)될 때 수축(팽창)하려는 특징을 보인다. 이러 한 물성을 기반으로 NPR 물질들은 인공근육, 충격파 흡 수 재료나 센서 등 다양한 분야에 응용되고 있다.

이처럼, 메타물질은 물질의 구조를 설계하는 것만으 로도 독특한 물성을 가지게 할 수 있기 때문에, 이미 $3 \mathrm{D}$ 프린팅을 활용하여 다양한 구조들이 제작 및 연구되고 있다. 나아가 최근에는 메타물질을 스마트 소재로 제작 하여, 외부 환경에 따라 형태뿐만 아니라 물성 자체를 변화시키려는 시도들이 늘어나고 있다. 예를 들어, 하이 드로겔과 같은 기존의 소프트 재료는 수분 흡수시 양의 팽윤비를 보였던 것과 달리, 하이드로겔 메타물질을 설 계하여 음의 팽윤비를 가지는 소프트 메타물질을 개발 할 수 있다. ${ }^{28)}$ 이를 위해서는, 스마트 재료를 이용하여 복잡한 반복 구조를 가지고 있는 형상을 제작하는 기술 이 중요하다. $3 \mathrm{D}$ 프린팅 기술 자체가 복잡하고 반복되 는 내부 구조를 구현하는데 매우 유리하기 때문에, $4 \mathrm{D}$ 프린팅에도 효과적으로 적용될 수 있다.

\subsection{4. 기타}

앞서 제시한 오리가미, 키리가미, 메타물질 외에 도 생체모방 구조 (Biomimetic structure), 직물구조 (Textile), 다중안정 구조 (Multi-stable structure), 무 게중심 제어 구조 등이 스마트 소재를 이용한 구조 설계 에 활용되고 있다. 예를 들어, 생체모방 구조의 하나인 텐세그리티 (Tensegrity) 구조는 기계적 물성이 상반되 는 두 소재를 네트워크 구조로 연결하여 상보적인 기계 적 물성을 만들어 낸다. 이 구조는 네트워크 구조의 복 잡도를 이용해 형상을 모방하거나 물성을 설계할 수 있
으며, 동일한 부피로 구조를 제작했을 때 더 많은 하중 을 지지할 수 있는 등의 장점을 가지고 있다. 최근, 형성 기억 고분자로 텐세그리티 구조를 제작하여, 프린팅된 구조물이 온도에 따라 2차원으로 전개되거나 3차원 텐 세그리티 (Tensegrity) 형태로로 복원되는 스마트 구조 가 제작되었다. ${ }^{29)}$ 이러한 다양한 구조적 설계 기법들을 기반으로, 스마트 소재와 $3 \mathrm{D}$ 프린팅을 기반으로 하는 $4 \mathrm{D}$ 프린팅 구조물의 복잡도가 점점 높아지고 있다. 다 양한 스마트 소재와 스마트 구조의 융합은 $4 \mathrm{D}$ 프린팅이 가능성과 응용분야를 확장하는데 큰 역할을 할 것이다.

\subsection{D 프린팅 설계 및 프린팅}

$4 \mathrm{D}$ 프린팅 사물의 제작과정은 $3 \mathrm{D}$ 프린터를 이용한 제작과, 프린팅된 사물의 자기조립 혹은 자극반응을 통 한 기능 변화라는 두 단계 과정을 거쳐야 한다. 그러므 로 $4 \mathrm{D}$ 프린팅은 프린팅될 사물의 설계와 더불어 최종 변형 형상의 시뮬레이션을 필요로 한다.

\subsection{1. 다물질 $3 \mathrm{D}$ 프린팅}

복잡한 형상 변화나 물성 변화를 구현하기 위해서는 여러 종류의 물질을 한번에 프린팅 할 수 있는 기술이 $4 \mathrm{D}$ 프린팅의 필수 요소이다. 현재 많은 일반인들을 대 상으로 상용화된 $3 \mathrm{D}$ 프린터들이 2 개의 노즐, 때때로 3 개의 노즐까지 지원하며 다물질 프린팅을 가능케 하고 있다. 아직 까지는 서로 다른 소재들 사이의 접합 및 프 린팅 환경 제어 등 해결해야할 문제들이 많지만, $3 \mathrm{D}$ 프 린팅 뿐만 아니라 $4 \mathrm{D}$ 프린팅의 가능성을 넓히기 위해서 는 반드시 해결되어야 한다. 오리가미 구조 역시 다물질 
a)

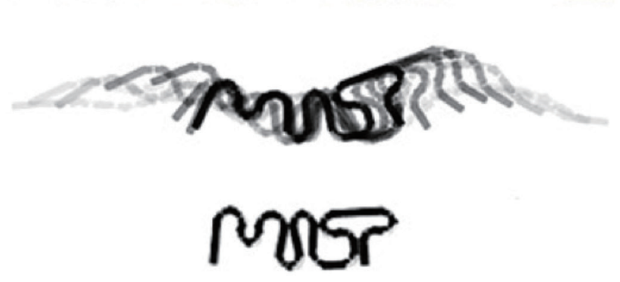

b)

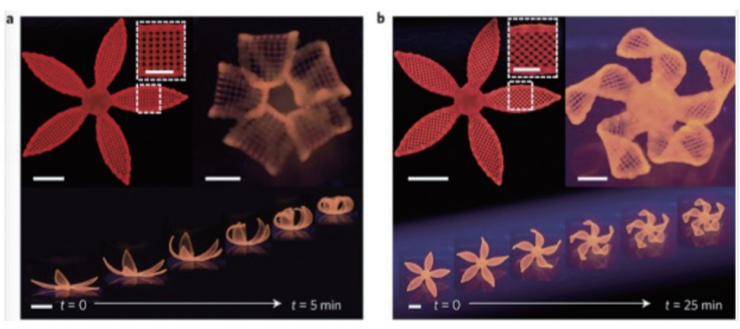

Fig. 5. a) 다물질 프린팅 기반 오리가미 b) 프린팅 패턴을 이용해 서로 다른 반응을 보여주는 단물질 오리가미 ${ }^{2)}$

프린팅을 효과적으로 사용해야하는 구조이다. 오리가미 구조의 접히는 부분은 스마트 소재로, 움직이는 면 부 분은 정적 소재로 프린팅하는 하는 등 어떤 부분에 어떤 재료를 이용하는지에 따라 같은 자극에도 구조가 변형 되는 정도를 제어할 수도 있기 때문이다.

다물질 프린팅을 기반으로 한 오리가미 구조의 대표 적인 예는 MIT의 자가조립연구소와 세계적인 3D 프린 터 회사인 스트라타시스 (Stratasys)가 협업하여 다물질 3D 프린터 (Multi-material 3D printer)를 이용해 만 든 구조들이라 할 수 있다. 이 구조들은 물과 접촉하며 팽창하는 극친수성 고분자 복합체와 강성의 다른 고분 자 복합체를 함께 프린팅하여 만들어진다. 물이라는 외 부 환경에 대해 두 물질의 반응에 차이가 나기 때문에, 해당 구조는 프로그래밍된 모양으로 스스로 변형될 수 있다. 예를 들어 1 차원의 선형 구조가 'MIT'로 형상이 변 하기도 하며, 2 차원 전개도 구조가 육면체 형상으로 변 하기도 한다. ${ }^{7}$ 이처럼 서로 다른 종류의 물질을 어떻게 배치하고 디자인하느냐에 따라, 다양한 자극에 반응하 는 다기능 스마트 시스템을 설계할 수 있다.

혹은, 여러 물질을 프린팅에 사용하지 않더라도, 한 가지 물질의 프린팅 패턴과 적층 두께 등을 위치마 다 달리하여 다물질의 효과를 내는 경우도 있다. MIT 의 자가조립연구소에서 제시한 프로그램 가능한 나무 (Programmable woods)는 한 물질로도 다물질의 효과 를 낼 수 있는 것을 보여준다. 한 종류의 목재 복합체를 이용하더라도, 프린팅되는 패턴과 두께를 달리하면 강 성 차이를 만들어낼 수 있기 때문에, 2 차원의 코끼리 전 개도 구조는 물에 들어가면 3 차원의 코끼리 형상으로 모
양이 바뀐다. 또는 이방적인 팽창률을 이용하여 집적 패 턴에 따라 반응을 달리하는 하이드로겔 구조를 제작할 수도 있다. 즉, 이러한 방식을 이용하면 같은 형상으로 출력된 물질도 서로 다른 반응성을 갖게 디자인할 수 있 다. ${ }^{12)}$ 하지만 이러한 방식으로 설계할 수 있는 구조와 기 능에는 한계가 있으므로, 다물질 프린팅이 반드시 필요 하다.

\subsection{2설계및 시뮬레이션}

$4 \mathrm{D}$ 프린팅의 핵심은 프린팅 된 2 차원 혹은 3 차원 구 조물이 원하는 상황과 자극에 따라 다른 적절한 구조 및 기능을 가지도록 바뀌는 것이다. $4 \mathrm{D}$ 프린팅에서의 변형 은 단순히 프린팅된 구조에서 스마트 소재가 변형되는 것을 반영할 수도 있고, 소재 변형에서 나아가 구조들 사이의 상호작용으로 더 복잡한 형상을 만들 수도 있다. 그러므로 $4 \mathrm{D}$ 프린팅 사물을 설계하고 구현하는데 있어 서는, $3 \mathrm{D}$ 프린팅된 구조 뿐만 아니라 자극 반응시 변화 될 형상을 예측하고 시뮬레이션할 수 있는 기술이 필수 적이다.

국내에서는 광주과학기술원 (GIST)의 이용구 교수 연 구팀이 $4 \mathrm{D}$ 프린팅 시뮬레이터를 개발 및 연구 중이다. $4 \mathrm{D}$ 프린팅 과정에서 목표 구조물을 구현하기 위한 스 마트 관절을 자동 배치 할 수 있는 자동 설계 방법을 제 시하고, 제작된 구조물과 목표 형상의 유사성을 검증하 였다. ${ }^{30)}$ 해외의 $4 \mathrm{D}$ 프린팅 시뮬레이터의 경우 코넬대학 (Cornell University) 연구팀에서 개발한 VoxCAD가 대표적이며, 연성로봇의 디자인 및 시뮬레이션에 활용 되고 있다. 소스코드가 공개되어 있는 오픈소스 소프트 
a)

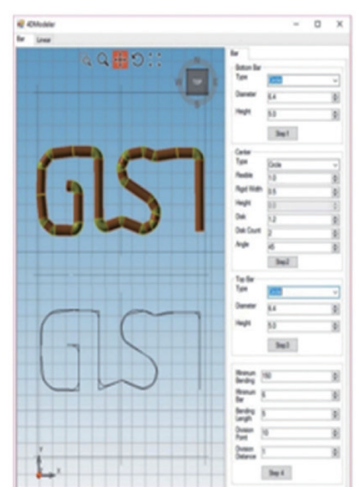

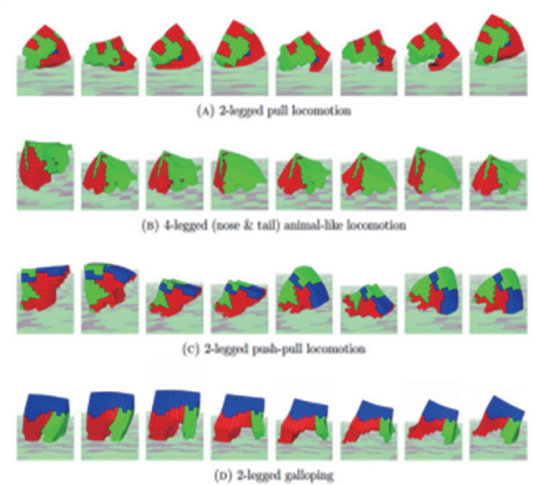

Fig. 6. a) GIST 연구팀의 $4 \mathrm{D}$ 프린팅 시뮬레이터 ${ }^{30}$ b) 코넬 대학 연구팀의 VoXCAD를 이용한 능동변형 구조 시뮬레이션 ${ }^{311}$

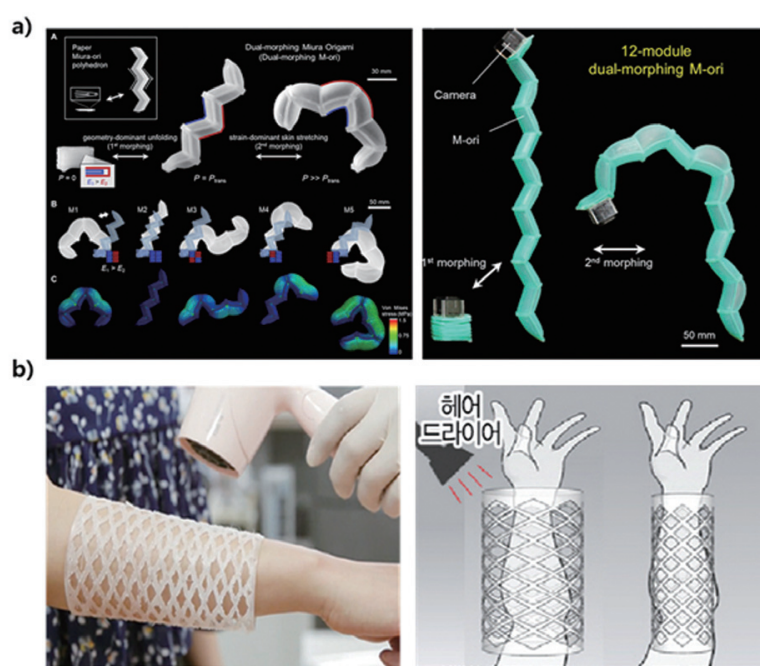

Fig. 7. a) 서울대학교 연구팀의 오리가미 구조를 이용한 소프트 로봇 ${ }^{32)}$ b) KIST 연구팀의 $4 \mathrm{D}$ 깁스

웨어이므로 필요에 따라 변형시켜 사용할 수 있다. ${ }^{31)}$ 이 외에도 오토캐드 (AutoCAD)가 개발한 4D 프린팅 시뮬 레이터 (Project Cyborg)가 존재하고, 기타 상용 소프트 웨어를 활용한 $4 \mathrm{D}$ 프린팅 시뮬레이션도 가능하다.

\section{3. 국내 및 해외 현황}

국내에서는 대표적으로 서울대학교 조규진 교수 연구 팀이 스마트 구조를 이용한 소프트 로봇 제작, GIST 이 용구 교수 연구팀이 4D 프린팅 시뮬레이션, KIST의 문 명운 계산과학연구센터장이 $4 \mathrm{D}$ 프린팅 소재 및 디자인 개발 등 유용한 시스템 제작 및 응용까지 아우르는 $4 \mathrm{D}$
프린팅 연구를 수행 중이다. 예를 들어 조규진 교수 연 구팀은 스마트 오리가미 구조를 기반으로 한 소프트 로 봇들을 선보였으며, ${ }^{32}$ 문명운 센터장 연구팀은 열을 가 하면 신체에 맞춤형으로 고정되는 $4 \mathrm{D}$ 깁스를 선보이기 도 했다.

국내 4D 프린팅 시장은 아직 크게 형성되어 있지는 않지만, 보건의료 및 산업적 응용보다는 시뮬레이션, 웨 어러블 기기, 생활용품 등에 $4 \mathrm{D}$ 소재의 활용이 집중되 어 있다. 그러나 $4 \mathrm{D}$ 프린팅 소재의 경우 $3 \mathrm{D}$ 프린팅 시 장에서도 활용될 가능성이 높기 때문에 $3 \mathrm{D}$ 프린팅 소재 를 보급하고 있는 기존 회사들의 접근이 용이하다. 또 한, $4 \mathrm{D}$ 프린팅 기술은 스마트 소재의 개발부터 설계 디 자인, 프린터, 시뮬레이션에 이르기까지 아직 해결해야 할 기술적 난제들이 매우 많으므로, 적극적인 투자와 집 중된 연구가 이루어진다면 세계시장을 선점하고 이끌어 갈 수 있을 것으로 기대된다.

국외에서는 대표적으로 미국의 MIT의 자가조립연구 소 (Self-assemblyLab)과 글로벌 3D 프린팅 선두기업 인 스트라타시스 (Stratasys)가 파트너십을 통하여, ${ }^{33)}$ 하버드 공대, 일리노이 공대가 정부의 지원 아래 $4 \mathrm{D}$ 프 린팅 기술이 연구 중이다. 이 밖에도 미국 디자인 업체 의 너브스 시스템은 $4 \mathrm{D}$ 프린팅 드레스, ${ }^{34)}$ 미국 재생의 학 업체 오가노보 홀딩스의 인공 간, ${ }^{35)}$ 독일의 자동차 제조사인 $\mathrm{BMW}$ 이 공개한 환경 조건에 따라 바퀴/좌 석 형상 등이 변화하는 자동차 '비전넥스트100 (Vision Next 100), ${ }^{36)}$ 등 다양한 분야에서 $4 \mathrm{D}$ 프린팅 기술이 적 


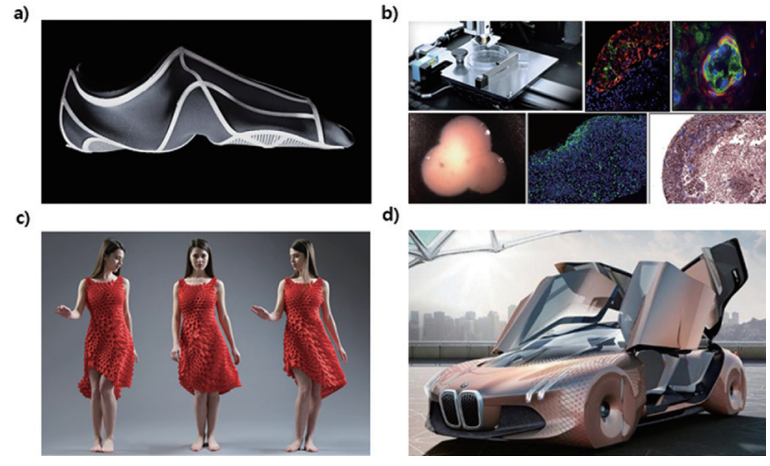

Fig. 8. a) MIT 연구팀의 4D 프린팅 Shape-shifting Shoe ${ }^{33)}$ b) 오 가노보 홀딩스의 인공 간 ${ }^{35)}$ c) 미국 디자인업체 너브스시스 템의 $4 \mathrm{D}$ 프린팅 드레스 ${ }^{34)} \mathrm{d}$ ) $\mathrm{BMW}$ 의 차세대 자동차 비전넥 스트 100 모식도 ${ }^{36)}$

\section{용되고 있다.}

학계에서는 자극반응형 스마트 소재, 스마트 구조 설 계, 다물질 프린팅, 바이오 프린팅 등 4D 프린팅의 요소 기술 연구들이 활발하게 진행되고 있으며, 소프트로봇, 웨어러블 디바이스, 조직공학 등의 다양한 분야와 융합 되어 그 응용 분야를 넓혀가고 있다. 스마트 소재와 $3 \mathrm{D}$ 프린팅 분야와 접목한 $4 \mathrm{D}$ 프린팅 기술을 발전시키면 큰 시너지를 얻을 수 있을 것으로 예상되며 $4 \mathrm{D}$ 프린팅 제 품은 패션/생활용품 시장에서 나아가 보건의료 분야 (헬 스 케어, 인공 근육, 인공 생체기관 등), 제조/패키징 분 야, 가전제품 분야 (스마트 센서 등), 사회 기반시설 분 야, 자동차/항공/방위산업 분야에 이르기까지 활발하게 응용될 것으로 기대된다.

\section{4. 결론}

지금까지 $4 \mathrm{D}$ 프린팅의 정의와 기술 요소들을 개괄적 으로 살펴보았다. 지능형 사물이라는 $4 \mathrm{D}$ 프린팅이 제시 하는 비전은 매우 높지만, 아직 해결해야 할 기술적 난 제들이 매우 많다. 특히, 프린팅 가능한 스마트 소재들 이 한정되어 있기 때문에 아직까지는 $4 \mathrm{D}$ 프린팅의 결과 물은 대체로 동력이 약하고 형상 변환 속도가 느리다. 또한 대부분 제작 과정에서 미리 정해진 물성에 따라 몇 가지 혹은 단순한 형태의 형상 변화만을 보여주고 있기 때문에 고도화가 가능한 진정한 '지능화'의 수준에 도달
하지 못한 상태이다.

그러므로, $4 \mathrm{D}$ 프린팅은 큰 강성이 요구되는 산업적 응용분야보다는 생활용품 분야와 더불어 생체 구조와 접목되는 의료 분야에서 좀 더 빠른 시기에 두각을 드러 낼 수 있을 것이라 예상된다. 특히, 생체 환경에서 구동 되어야 하는 삽입형 기기의 경우에는, 삽입 및 제거과정 에서 다양한 인터페이스를 활용할 수 있고, 구동 중에는 다양한 생체 환경 변화에 능동적으로 대응할 수 있는 스 마트 소재의 활용이 필수적이기 때문에 $4 \mathrm{D}$ 프린팅 소재 들이 활용될 여지가 매우 크다고 할 수 있다.

위에서 소개한 $4 \mathrm{D}$ 프린팅의 모든 기술요소 (소재, 구 조, $3 \mathrm{D}$ 프린팅, 설계, 시뮬레이션 등)들은 창의적이고 도전적인 접근을 요구하며, 특히 복잡한 시스템을 제작 하기 위해서는 $4 \mathrm{D}$ 프린팅에서 나아가 재료공학, 기계공 학, 전기공학, 컴퓨터공학, 생명공학 등에 이르기까지 거의 모든 공학을 아우르는 융복합적 접근이 필요하다. 이 목표를 향해가는 과정에서 다양한 원천기술들이 개 발될 수 있으며, 이는 4차 산업혁명 시대에 진정한 시물 지능을 구현하는데 다양한 방면에서 도움이 될 것이다. 이러한 과정을 거쳐 멀지 않은 미래에, $4 \mathrm{D}$ 프린팅 기술 의 발전은 $3 \mathrm{D}$ 프린팅이 가져다줄 것이라 예상하는 산업 구조의 변화 수준을 넘어서, 물리적 세계에 대한 인식 자체를 달리하는 파급력 있는 사회적 효과를 가져올 수 있을 것으로 기대된다.

\section{REFERENCES}

1. C. Goldstein, J. D. Campbell and T. C. Mowry, "Programmable matter," Computer, 38 [6] 99-101, (2005).

2. M. Brambilla, E. Ferrante, M. Birattari, M. Dorigo, "Swarm robotics: a review from the swarm engineering perspective," Swarm Intell., 7 [1] 1-41 (2013).

3. A. Pamecha, I. Ebert-Uphoff and G. S. Chirikjian, "Useful metrics for modular robot motion planning," IEEE Transactions on Robotics and Automation, 13 [4] 531-545 (1997).

4. S. Tibbits, "Skyler Tibbits: The Emergence of 
4D Printing,"TED, (2013)., Available: http:// www.ted.com/talks/skylar_tibbits_the_ emergence_of_4d_printing.

5. F. Momeni, S.M.M. Hassani, N.X. Liu, J. Ni, "A review of 4D printing," Mater. Des., 122 42-79 (2017).

6. D. Raviv, W. Zhao, C. McKnelly, A. Papadopoulou, A. Kadambi, B. Shi, S. Hirsch, D. Dikovsky, M. Zyracki, C. Olguin, R. Raskar, S. Tibbits, "Active printed materials for complex self-evolving deformations," Sci. Rep., 47422 (2014).

7. S. Tibbits, " $4 \mathrm{D}$ printing: Multi-material shape change." Architect. Des., 84 [1] 116-121 (2014).

8. C. Majidi, "Soft-Matter Engineering for Soft Robotics," Adv. Mater. Technol., 4 [2] 1800477 (2019).

9. L. Hines, K. Petersen, G. Z. Lum, M. Sitti, "Soft Actuators for Small-scale Robotics," Adv. Mater., 29 [13] 1603483 (2017).

10. E. Lee, D. Kim, H. Kim, J. Yoon, "Photothermally driven fast responding photo-actuators fabricated with comb-type hydrogels and magnetite nanoparticles," Sci. Rep., 5, 15124 (2015).

11. Y. Kim, H. Yuk, R. Zhao, S. A. Chester, X. Zhao, "Printing ferromagnetic domains for untethered fast-transforming soft materials", Nature, 588 [7709] 274-279 (2018).

12. A. S. Gladman, E. A. Matsumoto, R. G. Nuzzo, L. Mahadevan, J. A. Lewis, "Biomimetic 4D printing," Nat. Mater., 15 [4] 413 - 418 (2016).

13. G. Liu, Y. Zhao, G. Wu, J. Lu, "Origami and 4D Printing of Elastomer-derived Ceramic Structures," Sci. Adv., 4 [8] (2018).

14. J. L. Silverberg, J.-H. Na, A. A. Evans, B. Liu, T. C. Hull, C. D. Santangelo, R. J. Lang, R. C. Hayward, I. Cohen, "Origami structures with a critical transition to bistability arising from hidden degrees of freedom," Nat. Mater., 14 [4] 389-393 (2015).

15. N. C. Seeman,"Nucleic acid junctions and lattices," Journal of theoretical biology, 99 [2] 237-247, (1982).

16. P. W. K. Rothemund, "Folding DNA to create nanoscale shapes and patterns," Nature, 440
[7082] 297-302 (2006).

17. J. A. Faber, A. F. Arrieta, A. R. Studart, "Bioinspired spring origami," Science 359 [6382] 1386- 1391 (2018).

18. E. Hawkes, B. An, N. M. Benbernou, H. Tanaka, S. Kim, E. D. Demaine, D. Rus, R. J. Wood, "Programmable matter by folding," Proc. Natl. Acad. Sci. U.S.A., 107 [28] $12441-$ 12445 (2010).

19. L.Wilson, S.Pellegrino, Rolf Danner, "Origami sunshield concepts for space telescopes," 54th AIAA/ASME/ASCE/AHS/ASC Structures, Structural Dynamics and Materials Conf., 1594 (2013).

20. A. Lamoureux, K. Lee, M. Shlian, S. R. Forrest, M. Shtein, "Dynamic kirigami structures for integrated solar tracking," Nat. Commun., 68092 (2015).

21. M. K. Blees, A. W. Barnard, P. A. Rose, S. P. Roberts, K. L. McGill, P. Y. Huang, A. R. Ruyack, J. W. Kevek, B. Kobrin, D. A. Muller, P. L. McEuen, "Graphene kirigami," Nature 524 [7564] 204- 207 (2015).

22. A. Rafsanjani, Y. Zhang, B. Liu, S. M. Rubinstein, K. Bertold, "Kirigami skins make a simple soft actuator crawl,"Sci. Robot., 3 [15] eaar7555 (2018).

23. A. Rafsanjani, L. Jin, B. Deng, K. Bertoldi, "Propagation of pop ups in kirigami shells," Proc. Natl. Acad. Sci. U.S.A., 116 [17] 8200 (2019).

24. T.H.Kwok, C.C.L. Wang, D. Deng, Y. Zhang, Y. Chen, "4D printing for freeform surfaces: design optimization of origami and kirigami structures," Trans. ASME, J. Mech. Des. 137 [11] (2015).

25. D. R. Smith, W. J. Padilla, D. C. Vier, S. C. Nemat-Nasser, S. Schultz,"Composite medium with simultaneously negative permeability and permittivity,"Phys. Rev. Lett. 84 [18] 4184 (2000).

26. K. Bertoldi, P.M. Reis, S. Willshaw and T. Mullin, "Negative Poisson's Ratio Behavior Induced by an Elastic Instability," Adv. Mater., 22 [3] 361-366 (2010).

27. J.T.B. Overvelde, S. Shan and K. Bertoldi," Compaction Through Buckling in 2D Periodic, 
Soft and Porous Structures: Effect of Pore Shape,"Adv. Mater, 24 [17] 2337-2342 (2012).

28. H. Zhang, X. Guo, J. Wu, D. Fang, and Y. Zhang, "Soft mechanical metamaterials with unusual swelling behavior and tunable stressstrain curves," Sci. Adv., 4 [6] eaar8535 (2018).

29. K. Liu, J. Wu, G. H. Paulino, H. J. Qi, "Programmable Deployment of Tensegrity Structures by Stimulus-Responsive Polymers," Sci. Rep., 7 [1] 3511 (2017).

30. S. Ham, and Y.G. Lee., "A study on the automatic design of 4D printing to follow the target shape," Korea Journal of Computational Design and Engineering 21 [3] 306-312 (2016).

31. N. Cheney, R. MacCurdy, J. Clune, and H. Lipson, "Unshackling evolution: evolving soft robots with multiple materials and a powerful generative encoding," ACM SIGEVOlution 7 [1] 11-23 (2014).

32. W. Kim, J. Byun, J. Kim, W. Choi, K. Jakobsen, J. Jakobsen, D. Lee, and K. Cho.

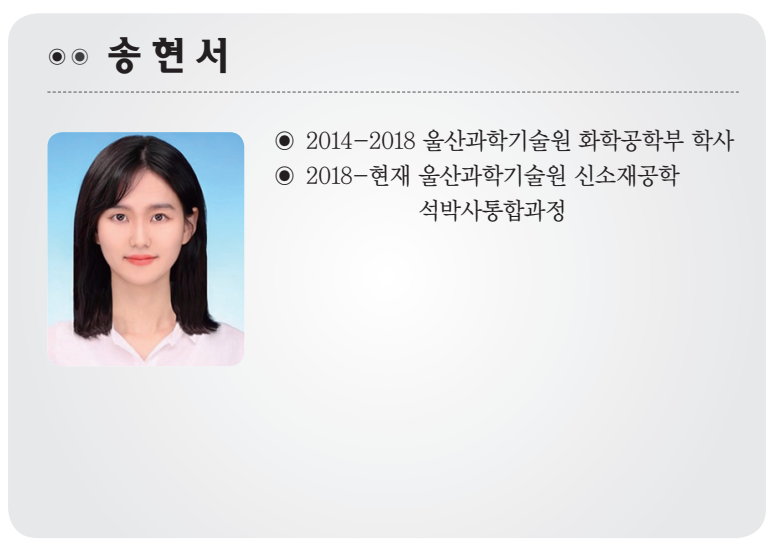

"Bioinspired dual-morphing stretchable origami," Sci. Robot., 4 [36] eaay3493 (2019).

33. "MIT Self Assembly Lab creates Shapeshifting Minimal Shoe," All3DP, last modified Nov 10, 2015, accessed Fab 28, 2020, www. all3dp.com/mit-self-assembly-lab-minimalshoe/

34. J.Rosenkrantz, J.L.-Rosenberg,"Dress/code democratising design through computation and digital fabrication, "Architectural Design, 87 [6] 48-57 (2017).

35. "Organovo Subsidiary Samsara Sciences Launches Commercial Operations, Will Be Dedicated Cell Provider for 3D Bioprinting Company," 3Dprint.com, last modified Jan 13, 2016, accessed Fab 28, 2020, www.3dprint. com/115090/organovo-samsara-sciences/2/

36. "BMW i Next : une voiture lectrique autonome pour 2021," Automobile Propre, last modified May 14 2016, accessed Fab 28, 2020, www. automobile-propre.com/breves/bmw-inext-voiture-electrique-autonome-2021/

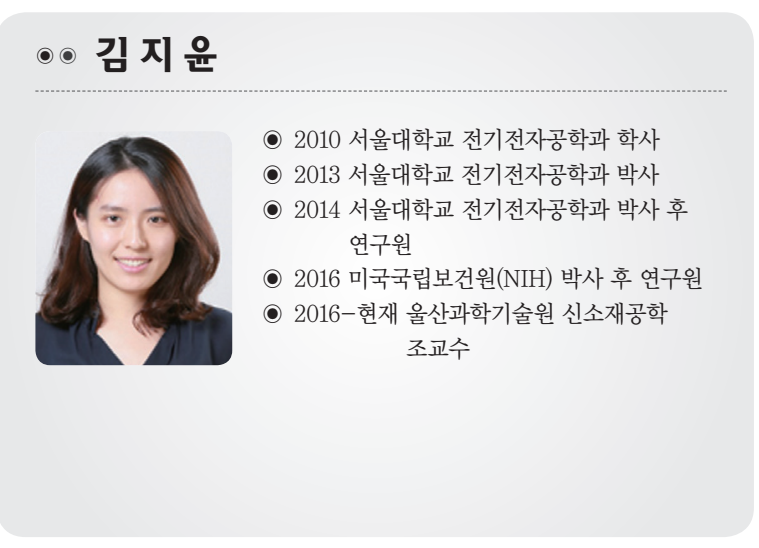

